\title{
Relationship of Emotional Maturity and Couples Adjustment on the Aircraft Crew
}

\author{
Hendro Prabowo \\ Faculty of Psychology \\ Gunadarma University \\ Depok, Indonesia \\ ndrahu@yahoo.com
}

\author{
Maria Chrisnatalia \\ Faculty of Psychology \\ Gunadarma University \\ Depok, Indonesia \\ mariachrisnatalia@gmail.com
}

\author{
Ajeng Sekar Lasenda \\ Faculty of Psychology \\ Gunadarma University \\ Depok, Indonesia \\ ajengsl@gmail.com
}

\begin{abstract}
This research is purposed to examine between emotional maturity and couples-social adjustment on commercial aircraft crew (pilots and flight attendants) with their partners. This research involved 90 respondents $(45$ couples) with ages ranging from 18 to 62 years old. We use a quantitative method with 100 participants and in this paper, we found 10 same couples working far apart from their partners. Data collection using emotional maturity scale and couples social adjustment scale. The results of the study showed that emotional maturity and couples social adjustment had a very significant positive relationship (Pearson correlation value was .319 with a significance value of .002 (p $<.01)$ ). Implications for working time arrangements for pilots and flight attendants are discussed.
\end{abstract}

Keywords: emotional maturity, couples social adjustment, commercial aircraft crew

\section{INTRODUCTION}

Having a relationship is certainly a common thing considering that basically, humans are social creatures, this relationship namely are friendship relationships, family relationships, or love relationships. Love relationships or romantic relationships are beautiful relationships, based on feelings of love for others and can be shown in various ways. However, there are also various situations in this love relationship, one of which is a long-distance relationship.

Long-distance relationship a geographical separation between couples who are undergoing a romantic relationship. According that the couples can be said to have a long-distance relationship if the couples spends at least two separated nights [1]. While Rabe [2] state the LDR is determined if the couples spend four separate night on weekdays with other criteria such as having a different place to live and pursuing a career. Guldner \& Swensen [3] also explained that couples who rarely speak, face-to-face time is not much and physically together for an average of 23 days can also be said to be undergoing a long-distance relationship. This is indeed not an easything, because an individual must leave his/ her spouse for a long time may be due to work problems or may take further education in another country. Living this long-distance relationship is also not an an easything because of the lack of intensity of communication and meeting. Like wish for commercial flight crews with their partners, such as the study put forward by Holmes [1] and Rabe [2] in accordance with commercial flight crews must leave their partners for work at least two to four days.
According to the research result of Horn, Arnone, Nesbitt, Desllets, Sears, Giffin, \& Brudi [4] about college student long-distance relationships $(N=80)$ which is compared with those that were not long-distance $(N=82)$ on nine variables that have been suggested as fundamentally important in intimate relationships. The long-distance relationships (LDRs) members is stated that they have less descriptive self-disclosure and companionship with their partners, affection, enhancement of worth, instrumental help, nurturance, and partner's perspective-taking. NonLDRs did not differ from LDRs on ratings of closeness, but were rated as less satisfactory. LDRs were no more likely to terminate within a 3-month period than were non-LDRs.

This study compared long-distance romantic relationships of students $(\mathrm{N}=80)$ with those who did not distance $(\mathrm{N}=82)$ on nine variables that have been suggested as fundamentally important in intimate relationships. The relationship members (LDRs) reported self-disclosure and friendship less descriptive with their partners, and they are less sure their relationship will last. Two types of relationships do not differ in the remaining six processes of intimacy: intimate self-disclosure, affection, value enhancement, instrumental assistance, parenting, and partner perspective taking. Not different from non-LDR in proximity rankings, but considered unsatisfactory. LDRs were no more likely to end in a 3-month period than nonLDRs. In all samples, relationship satisfaction was found to be the best predictor of stability.

Stafford \& Reske [5] explored the phenomenon of idealization in college premarital long-distance relationships. Here, 71 college couples participated in a survey. Findings indicate that long-distance couples have more restricted communication and are more idealized than their geographically close partners. In addition, an associative pattern between restricted communication and positive relational images is found. Speculation is offered that long-distance couples, due to their limited contact, postpone realistic assessments. Long-distance couples have more limited communication and are more idealized than their geographically close counterparts. Furthermore, the pattern of relations between communication is limited and positive relational images are found. Speculation offered is long-distance partners, because of their contact limited, delaying realistic assessment.

Handrini [6] describes how the relationship between pilot work is related to problems with their partners. The 
pilot's work schedule is far different from the schedule of the common people. Even though they have an unusual schedule, pilots can get 12 days for holidays. In addition, the pilot work schedule is not like the routine work schedule of the common people, where they leave at the same time and go home at the same time. Pilots can start work at night at 7:00 and return in the morning at 6:00. Sometimes they can get more than 10 leg rations which means their partner must be left for 3 days. It is not unusual if they have breakfast in Jakarta, have lunch in Surabaya, then have dinner in Banjarmasin. In addition, they must be prepared to receive telephone calls asking where they are and ready to reschedule, or suddenly get a flight call, especially if the status is stand-by. As a result, emotional maturity is important for both partners.

According to the research results of Azizah \& Kumala [7], emotional maturity has an influence of $67.5 \%$ on the happiness of a marriage partner who has a long-distance relationship. Chaplin [8] defines emotional maturity as a condition or condition in achieving maturity in a person's emotional development. People who have mature emotions, will not display emotional patterns that are only appropriate for children. According to Schneider [9] emotional maturity is one of the factors of good social adjustment. Social adjustment according to Chaplin [8] is part of adaptation or adaptation. Social adjustment means harmonizing relationships with the social environment, learning the behavioral patterns needed, or changing existing habits so that they are suitable in society.

Based on the above review, the research question formulates whether there is a relationship between emotional maturity and couples social adjustment of commercial flight crew and their partners?

\section{RESEARCH METHOD}

The hypothesis in this study is that there is a relationship between emotional maturity and couples social adjustment of commercial flight crew and their partners. Couples social adjustment is the ability to build and maintain good and satisfying relationships to avoid negative pressure or other people's egocentrism between individuals and their partners. In this study, the couples social adjustment was measured using the Couples Social Adjustment Scale based on aspects of social adjustment from Schneiders [9], included: recognition (respecting and accepting the rights of others), participation (involving themselves in relationships), social approval (interest and sympathy for the welfare of others), altruism (having a humble and unselfish nature), and conformity (respecting and obeying values - integrity of law, tradition and customs). The Couples Social Adjustment Scale has 38 items with Alpha reliability $=.916$.

Emotional maturity is a condition where the personality continues to strive for a healthy level of emotion, can critically assess the situation before acting and will not display emotional patterns that are only appropriate for children. Emotional maturity will be measured by the Emotion Maturity Scale based on the characteristics of emotional maturity proposed by Smitson (cited in [10]), including; towards independence, the ability to accept reality, adaptability, readiness to respond, capacity to be balanced, ability to empathize, and the ability to master anger. This Emotion Maturity Scale consisted of 17 items with Alpha reliability $=.772$.

The population characteristics in this study were commercial flight crews (pilots and flight attendants) and their partners and had undergone long-distance relationships for approximately six months. The samples taken were 45 long-distance couples who one of their partners worked as a commercial flight crew, with a purposive sampling technique, a sampling based on certain considerations or based on research characteristics that have been determined.

\section{RESULT}

\section{A. Respondent Demographic}

From the results of questionnaire distribution on 100 respondents (50 pairs), 24 pilots and 26 flight attendants were obtained, with an average length of flight of 3,545 hours and domestic flight routes of 13 respondents, international one respondent, and domestic and international 36 respondents. Married respondents were 18 couples and 32 couples were still dating. In this study, 10 respondents (5 couples) could not be analyzed because it was an outlier, so the remaining 90 respondents (45 couples) were used as research samples.

Of these 45 couples, there are 10 couples where both parties have jobs with a geographical location far from the place of residence, so that they can be far from each other and the 10 subjects are in TABLE I.

\section{B. Hypothesis Testing and Discussion}

Based on the results of hypothesis testing in 90 respondents (45 pairs), it was found that the Pearson correlation value was .319 with a significance value of .002 $(\mathrm{p}<.01)$ which means that there is a very significant relationship between emotional maturity and couples social adjustment of the commercial flight crew and their partners. The direction of the correlation in this study has a positive, this means that the higher the emotional maturity, the higher the couples social adjustment. Vice versa, the lower the emotional maturity, the lower the couples social adjustment.

Schneider [9] revealed that one of the factors of good social adjustment is development and maturity, this includes emotional maturity, if someone's emotions mature then the social adjustment will be good. It is supported by some previous studies.

Dean [11] studied 117 couples from a middle-class community. By use the Dean Emotional Maturity Scale and the Nye Scale of Marital Adjustment, Dean found that the husband's emotional maturity correlated .28 with marital adjustment; his emotional maturity as rated by his wife (independently and confidentially) correlated .52. The wife's emotional maturity correlated with her marital adjustment score .35; her emotional maturity correlated .39. Marital adjustment scores correlated with each other .59. In addition, Cole, Cole, \& Dean [12] reported the results of a 
decade replication of research investigating the relationship between both spousal and separated emotional maturity and the marital adjustment of both spouses. They used a random sample of 117 husband-wife pairs as the same with previous research of Dean [11].

TABle I. 10 Unique Partner Identities That Have the SAme Work as Geographical SeParation Based on Questionnarie

\begin{tabular}{|l|l|l|l|l|l|c|c|}
\hline \multirow{2}{*}{$\begin{array}{c}\text { No } \\
\text { subject }\end{array}$} & \multirow{2}{*}{$\begin{array}{c}\text { Name } \\
\text { (Sex) }\end{array}$} & Age & \multicolumn{1}{|c|}{ Job } & Status & $\begin{array}{c}\text { Length of } \\
\text { relationship } \\
\text { (Year) }\end{array}$ & Age & Identity of Couples \\
\hline 7 & MN (M) & 22 & Pilot & Dating & 4 & 27 & Pob \\
\hline 22 & D (M) & 23 & Pilot & Dating & 3 & 22 & Flight attendant \\
\hline 39 & B (M) & 23 & Pilot & Dating & 1 & 23 & Flight attendant \\
\hline 33 & IS (F) & 29 & Flight attendant & Married & 6 & 31 & Flight attendant \\
\hline 14 & L (F) & 34 & Flight attendant & Married & 2 & 29 & Pilot \\
\hline 21 & A (F) & 21 & Flight attendant & Dating & 2 & 25 & Pilot \\
\hline 20 & R (F) & 22 & Flight attendant & Dating & 7 & 22 & Seafarer \\
\hline 23 & E (F) & 24 & Flight attendant & Dating & 2 & 24 & Aircraft Engineer \\
\hline 24 & L (F) & 24 & Flight attendant & Married & 1 & 26 & Officer of the Ministry of Oceanology \& Fishery \\
\hline 26 & J (F) & 27 & Flight attendant & Married & 8 & 32 & Tour Leader \\
\hline
\end{tabular}

Using the Dean Emotional Maturity Scale and the LockeWallace Short Form, they concluded that husband's emotional maturity correlated .33 with his and .28 with his wife's marital adjustment; husband's emotional maturity (rated independently and confidentially by wife) correlated .27 with his and .51 with his with marital adjustment; wife's emotional maturity correlated .39 with her and .09 with her husband's; wife's emotional maturity (rated independently and confidentially by husband) correlated .20 with her and .23 with her husband's marital adjustment. Marital adjustment of husband and wife correlated at .50.

Weiten \& Lloyd [13], Eshun [14] stated a high average score on the emotional maturity and social adjustment of the partner is showed by the respondent although they are doing a long-distance relationship. Mainly in the social adjustment of the pair, this is due to an adjustment or adjustment. A person's response to changes that occur around him, which effects in the person trying to overcome the demands and challenges in everyday life and the process is related to how one overcomes pressures of the environment and their problems, it is called as the definition of adjustment. Another ideas is from Arkoff (cited in [15]), he stated that adjustment is an effort to balance the conditions themselves with the expected conditions of the environment from the interaction of individuals with their environment.

\section{RECOMMENDATIONS}

A brief at operational level is important to be developed when flight crews are faced with the uncertainty of flight schedules, while they also have to communicate increasing social adjustment with their partners. Cahill, McDonald \& Losa [16] stated that it is possible to transform the way the preflight, flight planning, and briefing task is performed for the better. Unless they are changing the flight operations process and in particular, changing what information is communicated to flight crew in the flight plan and how it is communicated. It is to be concerned because uncertainty job can result in psychological on pilots and flight attendants such as sleep disturbances, fatigue, feeling depressed or anxious [17].
According to Avers, King, Nesthus, Thomas, \& Banks [18] the scheduling factors made up 9 of the 10 most common operational change recommendations that flight attendants proposed to reduce flight attendant fatigue. 93\% indicated that flight attendant fatigue represents a safety risk, and $91 \%$ agreed that fatigue was a common occurrence which is based on survey to 9,180 cabin crew members.

And for cabin crew to be able to foster a good relationship with a partner can use chat or video calls to make it easier to interact with a partner

\section{REFERENCES}

[1] Holmes, Mary. "The emotionalization of reflexivity". Sociology. Japan, Vol 44 pp 139-154, 2010.

[2] Rabe, M. E. "Commuter couples': An inside story". Society in Transition, vol 32, pp 277-291. 2001.

[3] Guldner, Gregory T.; Swensen, Clifford H. "Time spent together and relationship quality: Long-distance relationships as a test case". Journal of social and Personal Relationships, vol 12, pp 313320. 1995.

[4] Horn, K. R. V., Arnone, A., Nesbitt, K., Desllets, L., Sears, T., Giffin, M., \& Brudi, R.. Physical Distance and Interpersonal Characteristics in College Student's Romantic Relationships. Personal Relationships, vol 4, pp 25-34. 1997.

[5] Stafford, L., \& Reske, J. R. Idealization and Communication in LongDistance Premarital Relationships. Family Relations, 1990.

[6] Handrini. Become a Pilot's Wife? Who? https://www.kompasiana.com/handrini/550b0e54a33311b1142e39ec/ menjadi-istri-pilot-siapkah, 2011 (in Indonesian).

[7] Azizah, A. Kumala, Can Intimacy and Emotional Maturity Affect the Happiness of Marriage in a Long Distance Relationships Partner (in Indonesian). Proceedings of the National Conference of Young Psychologist Research in Indonesia, 1(1). 39-45. http://proceedings.psikologi.uhamka.ac.id/index.php/prosiding/article/ view/91, 2016.

[8] C. P. Chaplin, Complete Dictionary of Psychology. Jakarta: Rajawali Press Grafindo Persada, 2005.

[9] A. A. Schneiders, Personal Adjustment and Mental Health. New York: Rinehart and Winston, 1960.

[10] L. Gorlow, W, Katkovsky, The Psychology of Adjustment Current Concept and Application; $3^{\text {rd }}$ Edition. New York: Mc. Graw-Hill Co, 1976.

[11] D. G. Dean, "Emotional Maturity and Marital Adjustment". Journal of Marriage and the Family, vol 28, pp 454-458, 1966. 
[16] J. Cahill, N. McDonald, G. Losa, Understanding and Improving Flight Crew Performance of the Preflight, Flight Planning, and Briefing Task. The International Journal of Aviation Psychology, vol 23, pp 27-43, 2011. Family, pp 533-539, 1980.

[13] W. Weiten, M. A. Lloyd, Psychology Applied Modern Life: Adjustment in 21st Century (8th Ed.). California: Thomson Higher Education, 2006.

[14] S. Eshun, Relationship Between Outlook to Life and College Adjustment: An Analysis to the Role of Optimism in Stress Appraisal and Overall Mental Health Among College Students. Stress and Mental Health of College Students, pp187 -201, 2006.

[15] D. W. Tuttle, N. R. Tuttle, Self-esteem and Adjusting with Blindness: The Process of Responding to Life's Demands. Illinois: Charles C Thomas Publishers, LTD, 2004.
[17] A. D. O'Hagan, J, Issartel, A, Nevill, G. Warrington, Flying Into Depression: Pilot's Sleep and Fatigue Experiences Can Explain Differences in Perceived Depression and Anxiety Associated With Duty Hours. Workplace health \& safety, vol 65, pp 109-117, 2017.

[18] B. Avers, S. J. King, T. E. Nesthus, D. Thomas, J. Banks, Flight Attendant Fatigue, Part 1: National Duty, Rest, and Fatigue Survey (No. DOT/FAA/AM-09/24). FEDERAL AVIATION ADMINISTRATION OKLAHOMA CITY OK CIVIL AEROSPACE MEDICAL INST, 2009. 